\title{
The Citation Landscape of Scholarly Literature in LGBT Studies: A Snapshot for Subject Librarians
}

\author{
Karen Antell
}

This paper reports the results of a citation analysis of the scholarly literature of LGBT Studies. EBSCO's LGBT Life database was used to gather a sample of 4,321 citations from core scholarly journals in the field of LGBT Studies, covering the time period 1974 to 2010. The analysis reveals that, although LGBT Studies as an area of scholarship emerged from the gay rights activist movement of the 1960s and 1970s, the field's literature appears to be firmly rooted in the mainstream academic literature rather than in popular publications or community and activist periodicals. However, the field has a very high rate of cross-disciplinary citation and cites particularly heavily from medical journals and books. In addition to illuminating the citation characteristics of LGBT Studies, this paper presents lists of highly cited books and journals that should prove useful for subject librarians supporting LGBT Studies programs.

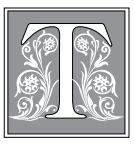

he field of Lesbian, Gay, Bisexual, and Transgender (LGBT) Studies is relatively new, having entered higher education only in the early 1970s with a small number of course offerings at the University of California at Berkeley, the City College of San Francisco (CCSF), the University of Nebraska, and a few other colleges and universities. The first degree programs were created in the late 1980s at the City University of New York and CCSF. ${ }^{1}$ Even today, LGBT Studies courses are not ubiquitous on college and university campuses, but the field is entering the academic mainstream, with undergraduate course offerings at many colleges and universities, certificate programs at dozens, degree programs at a few, and an endowed professorship at Harvard University. ${ }^{2}$ A few programs also have been developed in the United Kingdom and central Europe. ${ }^{3}$ Furthermore, strong graduate certificate programs at institutions such as Yale University, Indiana University, the University of Chicago, and the University of Michigan have begun producing new scholars whose "home field" is LGBT Studies. ${ }^{4}$ This is a contrast to previous decades, when

Karen Antell is Head of Reference and Outreach Services in Bizzell Memorial Library at the University of Oklahoma Libraries; e-mail: kantell@ou.edu. The author is grateful to EBSCO Publishing and EBSCO Account Executive Dana Beauvais for enabling temporary access to the EBSCO database LGBT Life during the data-gathering phase of this research. In addition, the author thanks Jaclyn Fulwood, Sean O'Brien, Carolyn Powell, Amy Rodgers, and Richard Tarver for data collection assistance and Lina Ortega for comments on an earlier draft of this manuscript. (C) 2012 Karen Antell, Attribution-NonCommercial (http:// creativecommons.org/licenses/by-nc/3.0/) CC BY-NC 
LGBT Studies scholars typically were specialists from the peripheries of other "allied" fields, often psychology, sociology, history, or social work. These new graduate programs and new scholars are contributing to a substantial increase in the number of scholarly papers published in the LGBT Studies literature over the past two decades, although authors from allied fields continue to be well represented in the literature as well. As a result, LGBT Studies literature remains highly interdisciplinary, with significant contributions coming from the fields of psychology, sociology, history, medicine, and social work.

For collection development librarians, the emergence of this new area of study creates the interesting challenge of providing library support to an interdisciplinary field without a long-standing body of scholarly literature. This challenge is exacerbated by the absence of most of the LGBT core journals from two ISI products: Web of Science, which allows citations to be searched, downloaded, counted, and analyzed; and Journal Citation Reports, which provides ranked lists of journals in many disciplines, as calculated by impact factor, number of citations, and other metrics. Both of these ISI tools are used frequently by librarians to aid in serials collection development, so the absence of LGBT Studies journals in the ISI products poses a challenge.

The EBSCO LGBT Life database is one important resource available to support research in LGBT Studies. Introduced in 2004, this database indexes the core scholarly journals of LGBT Studies as well as dozens of related journals and hundreds of monographs, nonscholarly periodicals, and other relevant publications. It is notable that, of the 63 core scholarly journals identified by LGBT Life, just $9(14 \%)$ are also indexed in Web of Science. Academic libraries' online subject guides consistently tout LGBT Life as the most important resource for access to the scholarly literature of LGBT Studies, ${ }^{5}$ and reviews in the professional literature are generally quite positive. One reviewer who compared LGBT Life's coverage with other databases' concluded that LGBT Life "is a unique, much-needed database." 6

However, no one resource can be expected to meet all of the research needs of a campus's LGBT Studies faculty and students. This raises the question of what additional resources are needed to support LGBT Studies programs, a question that is particularly salient because the field itself is so new: LGBT Studies has existed as an academic field for just 40 years, but its scholarly literature did not emerge from a vacuum. What sources does its scholarly literature draw on besides other scholarly literature in the same field? Did the first scholarly literature in LGBT Studies emerge from the scholarly literature of other fields, such as psychology, sociology, and medicine? Or did it draw mainly upon the activist literature of the gay and lesbian rights movement of the 1960 s or other nonscholarly sources? Is the field so new that it cites predominantly recent literature, or can a body of important historical sources be identified? The answers to these kinds of questions will help subject librarians provide access to the most important materials and teach the most relevant database search skills to support LGBT Studies programs. This study is a "backward-looking" citation analysis that answers such questions using data from the LGBT Life database.

\section{Literature Review}

No previous published study has focused on the citation landscape of LGBT Studies. However, citation analyses have been conducted for other interdisciplinary fields in the social sciences. Some papers report on the use of citation analysis to develop interdisciplinary core materials collections in specific interdisciplinary fields, such as Molly Strothmann's study of Social Work ${ }^{7}$ and Thomas Weissinger's two investigations of Black Studies. ${ }^{8}$ Both Strothmann's and Weissinger's analyses provide motivation for the inclusion of 
extradisciplinary journals in core journal lists for their respective disciplines. Strothmann's results indicate that, in addition to Social Work journals, a list of core Social Work journals should also include specific journal titles in psychiatry, psychology, medicine, and law. Weissinger's earlier paper is unique in suggesting that certain popular periodicals are part of the core literature of Black Studies: "Without mass culture popular periodical literature, Black Studies collections are incomplete because such literature plays a pivotal role in information transfer among Black Studies scholars." ${ }^{9}$ For instance, the Nation and the New York Times both are cited by more than 44 percent of the scholars studied by Weissinger.

In addition, some studies use citation analysis to assess the interdisciplinary or cross-disciplinary nature of a particular social sciences field, with the aim of informing collection development, library instruction, and the acquisition of indexing tools. Li Zhang, working with citations in International Relations, finds that just 38 percent of citations in International Relations journals are to other International Relations sources. The remaining 62 percent of citations come from numerous other fields, mainly from within the social sciences but also from law and the humanities..$^{10}$ Similarly, Strothmann's results include the finding that, in journals indexed in the major Social Work databases and on lists of core Social Work journals, only 36 percent of citations are to Social Work journals. ${ }^{11}$ In two even more extreme examples, Joy Thomas finds that fewer than 25 percent of citations in Social Work masters' theses are from Social Work journals, and Weissinger (in his later study) reports that only 23 percent of citations in two core Black Studies journals are to other Black Studies materials; fully 77 percent of citations are to journals in other fields. ${ }^{12}$ Weissinger thus concludes that some "traditional disciplinary journals" have a place on lists of core journals in Black Studies: “Traditional disciplinary journals are referenced a great deal in Black Studies literature, and [citation analysis] succeeds at capturing the esteem that scholars have for such material." ${ }^{13}$ In his (admittedly now dated) 1971 survey of multiple citation analyses, Robert Broadus examines the social sciences as a whole and finds that many citations fall outside the social sciences completely. For instance, citation analyses in Sociology show that 34 to 47 percent of citations are to materials not only outside Sociology but outside the social sciences altogether. ${ }^{14}$ Likewise, Penelope Earle and Brian Vickery report (in a 1969 study) that 58 percent of social science citations are from within the social sciences; thus, fully 42 percent are from outside the social sciences. ${ }^{15} \mathrm{~A}$ more recent study finds that median cross-disciplinary citation rates for the social sciences hover around 55 percent from 1980 to 2000, but with significant variations among disciplines and over time, from 19.5 percent (for Information Science and Library Science in 1980) to 81.5 percent (for Psychology in 2000). ${ }^{16}$

Many citation analyses measure the extent to which a discipline relies on monographs as opposed to serials. In the social sciences, a wide variety of results have been reported; neither journals nor monographs are clearly dominant. The numbers seem to vary not just by discipline but also over time. Amber Burtis and Mary Taylor find that, for Health Education articles published between 2006 and 2008, 73.2 percent of citations are to journal articles and 11.4 percent are to books; the remaining citations are to government documents, Web sites, and "miscellaneous" publications. ${ }^{17} \mathrm{On}$ the other hand, working with citations from the History of Technology, Katherine McCain reports that 65 percent of citations are to books and 35 percent are to serials. ${ }^{18}$ In International Relations, Zhang's results show that 48.2 percent of citations are to books and 38.8 percent are to journals; the remaining 13 percent encompass government documents, popular serials, conference papers, and other publication types. ${ }^{19}$ Broadus's 1971 
study surveys several different citation analyses in the social sciences and finds rates of monograph citation ranging from 30.9 to 55.6 percent, depending on the sample studied. Education and business administration show less reliance on books and more reliance on journals; for sociology, economics, and political science, the opposite is true. ${ }^{20}$ In a recent study of theses and dissertations, Nazan Özenç Uçak and Umut Al report that book citation rates in the social sciences average 62.7 percent, ranging from 26.2 percent for Psychology to 70.7 percent for Sociology. They also find that, with regard to publication type, the social sciences tend to fall between the humanities, which typically rely heavily on monographs, and the sciences, which tend to cite journals significantly more frequently than monographs. ${ }^{21}$ This is congruent with many other studies' results.

In addition, many citation analyses identify the age trends and "cited halflife" of cited works. These measures can aid in collection development and provide guidance for deselection by indicating which older works should be retained in the collection. Here, it is not surprising that findings from different studies are fairly similar: Publications tend to be cited most often in the first ten years after they are published and taper off relatively sharply thereafter, with monographs showing a gentler "decline" slope than journals. ${ }^{22}$ "Cited half-life," somewhat misleadingly, simply refers to the median age of a citation set. It gives an indication of how quickly or slowly literature becomes obsolete with age..$^{23}$ Thus, the cited half-life of monographs is typically larger than that of journals. Overall, the cited half-life calculated by authors of social science citation analyses tends to be less than 10 years. For example, Zhang finds the cited half-life of books in International Relations literature to be eight years; Earle \& Vickery calculate the cited half-life in general social sciences to be nine years overall and six years for serials. ${ }^{24}$ These examples highlight just a few of the many published social science citation analyses; they are not meant to be exhaustive but to give a general idea of the range of findings.

\section{Methodology}

This study is a citation analysis undertaken to discover the roots of LGBT Studies scholarly literature and provide a snapshot of the current "landscape" of the field's scholarly literature, with the goal of aiding in collection development and instruction for subject librarians who support academic programs in this field. More specifically, the study is an attempt to answer the following questions:

- Does LGBT Studies scholarly literature cite mainly other scholarly literature in the same field, or does it draw heavily on scholarly literature from other disciplines? In other words, how cross-disciplinary is the LGBT Studies literature?

- Did the first scholarly literature in LGBT Studies emerge chiefly from the scholarly literature of other fields, such as psychology, sociology, and medicine? Or did it rely heavily upon the activist literature of the gay and lesbian rights movement of the 1960s or other nonscholarly sources?

- Does this relatively new field cite predominantly recent literature, or can a body of important historical sources be identified?

- What are the most frequently cited scholarly journals, academic books, and other materials in the LGBT Studies literature?

The researcher conducted a citation analysis on a stratified random sample of scholarly articles from the core scholarly journals indexed in LGBT Life (EBSCO). Several periodicals listed by EBSCO as "core scholarly journals" were excluded from this study because they do not publish academic articles. For instance, Harvard Gay and Lesbian Review publishes essays, creative works, and reviews, and ReFresh, whose tagline is "culture, inte- 
riors, lifestyle, hot men and lots more," describes itself as a "lifestyle magazine"; neither includes scholarly articles. These two and several similar publications were therefore excluded from analysis. One article was selected from each core journal for every five years of its run in LGBT Life. Thus, a journal that had been indexed in LGBT Life for 20 years would be represented by four articles (one every five years), whereas a journal that had been indexed for only five years would be represented by just one article. To select the specific article within each five-year period for each journal, a random number generator (random.org) was used to select first an issue number and then an article number. For instance, if a journal produced 18 issues in a five-year period, a random number between one and 18 was chosen to select the issue; and if the selected issue contained six scholarly articles (book reviews and other nonpeer-reviewed articles were excluded), then a random number between one and six was chosen to select the article. Partial five-year periods were treated exactly the same as complete five-year periods; that is, a journal that was indexed for only two years had one article included, and a journal that was indexed for 16 years had four articles included. A total of 131 citing articles were selected, with publication dates ranging from 1974 to 2010.

For each of the 131 sampled articles from LGBT Life, the researcher collected all of the bibliographic citations included in the article's list of references and saved them to a Microsoft Access database. When complete, the database included 4,321 citations. Each citation was analyzed to determine its publication type, using the following list:

- Scholarly journals

- Academic books

- Government documents

- Biographies and memoirs

- Conference papers

- Creative works

- Popular books

- Popular periodicals (such as Glamour and the New York Times),
- Grey literature

- Special-interest nonscholarly periodicals (such as professional organizations' annual reports and activist groups' newsletters).

In addition, for four of the ten publication types-scholarly journals, academic books, popular books, and conference papers, totaling 3,651 citations-the citations were also assigned to one of five broad discipline categories: social sciences, humanities, science/technology, medicine, and law. These discipline assignments were made using primary subject headings in UlrichsWeb (for periodicals) and OCLC WorldCat (for books). The original citing articles selected from LGBT Life also were assigned to a discipline category.

Besides information about each citation's type and discipline, several additional items of information were added to the database: citation age, "out-ofdiscipline" status, and "in-database" status. The citation age was counted from the time of publication, not the present. For instance, a book published in 1973 and cited in an article published in 1993 was counted as a 20-year-old citation. For the 3,651 citations that were assigned a discipline category, each citation was determined to be either "in discipline" or "out of discipline" by comparing the discipline category of the citing articles in LGBT Life with that of the cited sources. For example, a social sciences book cited in a social sciences journal article was counted as an in-discipline citation, whereas a medical book cited in a humanities journal article was listed as out of discipline. Finally, for citations to scholarly journals, the "in-database" status was determined simply by checking to see whether the citation was to a scholarly journal indexed in LGBT Life.

\section{Results and Discussion Publication Type}

It was found that scholarly journals account for almost half $(47.3 \%)$ of all cited sources in the sample, and academic 
books account for about a third (34.2\%) (see figure 1). Together, then, these two scholarly publication formats make up 81.5 percent of all cited sources. This is remarkably congruent with the results of other citation analyses that report on publication type. For instance, Burtis and Taylor find that journals and books together make up 84.6 percent of citations in health education literature; Zhang, for International Relations literature, reports a similar 86.6 percent. ${ }^{25}$

Due to variations in the ways that different studies report publication type, it is difficult to compare these findings to other published data. However, it is worth noting that popular publications (periodicals and books) together make up 6.0 percent of all citations in this study. Although very few other citation studies report on the usage levels of popular materials, those that do present widely divergent results. For instance, Weissinger, studying a small group of influential authors in Black Studies, finds that fully 25.5 percent of periodicals cited by them are popular periodicals and newspapers, a remark- ably large proportion. He attributes this to Black Studies scholars' greater than typical degree of "boundary transcendence," a phrase he uses to "express the idea that Black Studies authors share information with colleagues in other disciplines by communicating outside the normal channels for intellectual discourse"; in other words, outside scholarly journals and academic books. ${ }^{26}$ Zhang, on the other hand, does not report specifically on citations to popular materials per se, but she does provide a breakdown of publication types that includes magazines and newspapers. In her study, these two types of popular periodicals make up just 2.2 percent of all citations (in International Relations). Unfortunately, her "books" category (accounting for 48.2 percent of all citations) does not distinguish between popular and academic books, so it is impossible to know whether popular books make up an appreciable proportion of citations in her study. ${ }^{27}$ It seems reasonable to suppose that LGBT Studies shares more in common with Black Studies than with International Relations: Both LGBT

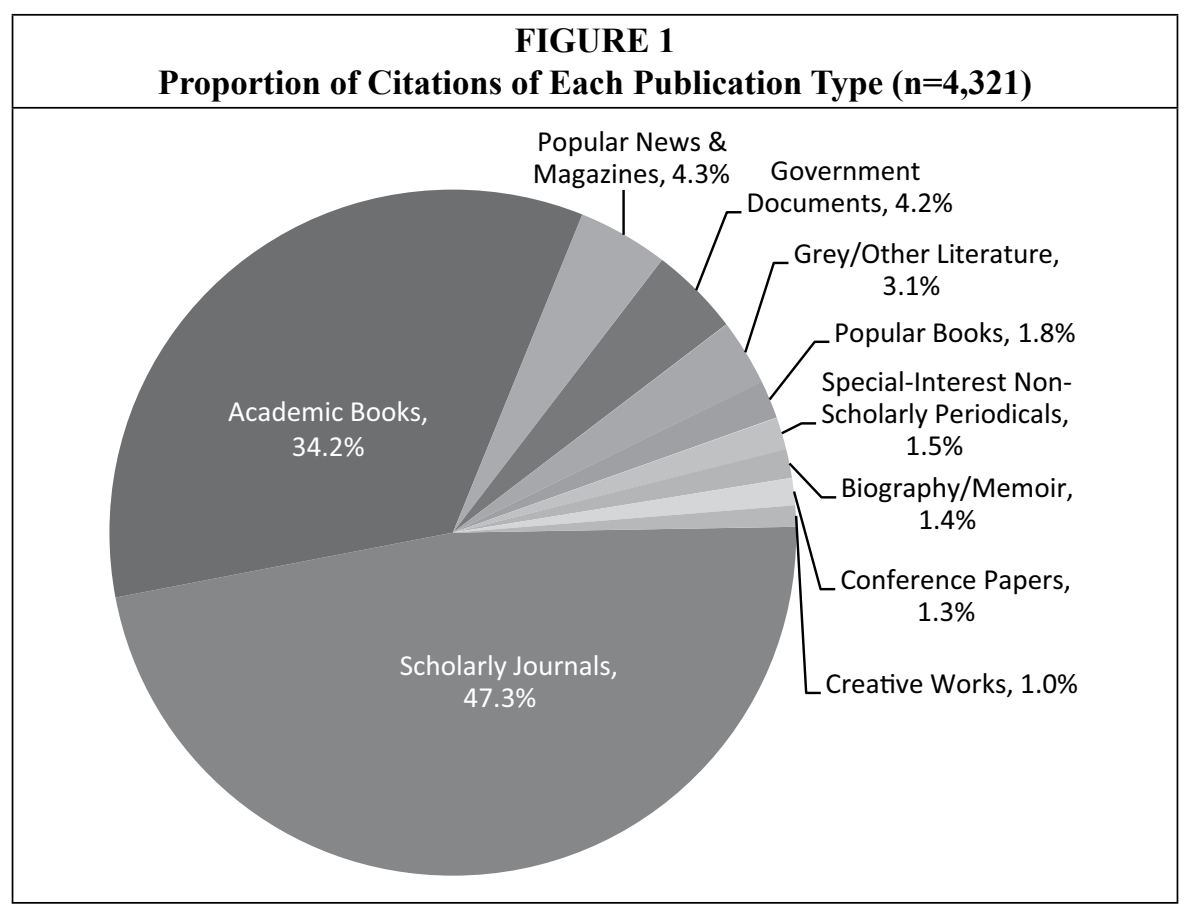


Studies and Black Studies stem from relatively recent activist movements and have only recently entered academia's mainstream. One might therefore expect LGBT Studies to show a degree of boundary transcendence similar to that of Black Studies and, as a result, to cite popular literature more frequently. It is not clear why Weissinger's results are so different from this study's results. One possible reason is that Wiessinger's research method is quite dissimilar to the current LGBT Studies

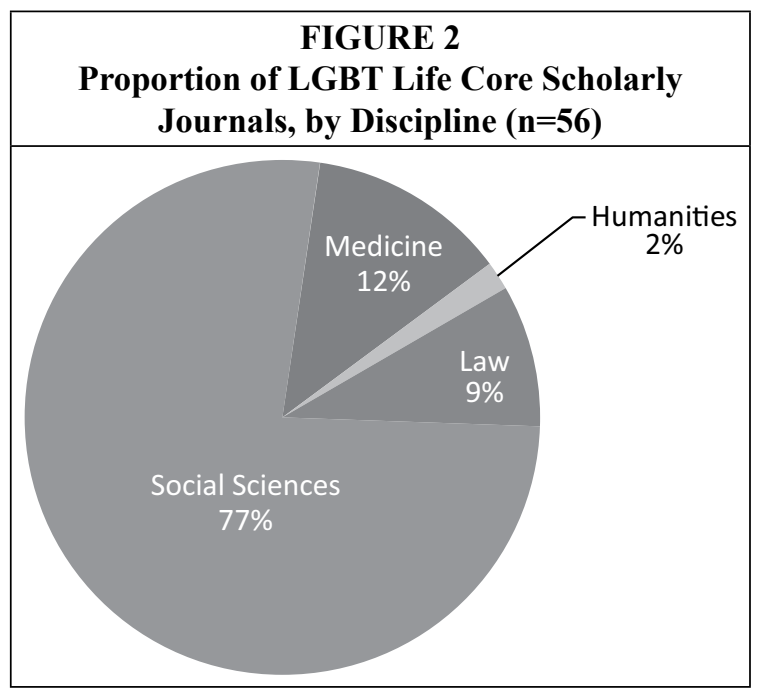
citation analysis, in that it focuses on a small number of influential scholars rather than an entire body of literature. Perhaps the most influential scholars' citation patterns are atypical in some way. In any case, though, this area is ripe for further investigation to address questions such as "how are popular books and periodicals used in the literature of 'activist' disciplines?" and "which kinds of popular books warrant a place in academic libraries' collections?"

\section{Discipline Category \\ Discipline Categories of the Citing Journals}

For each citation in the sample $(n=4,321)$, the citing journal was assigned to one of four broad discipline categories: social sciences, medicine, humanities, or law. Each citing journal, of course, is a core scholarly journal in LGBT Life. The 56 core scholarly journals are predominantly social science journals (43, or $77 \%)$, but medicine, law, and the humanities are also represented with seven, one, and five journals, respectively (see figure 2).

However, the social sciences journals account for more than their proportional share of citations, mainly because the social science journals tend to have longer runs of indexing in LGBT Life. Thus, for example, coverage of the medical journal

AIDS Patient Care and STDs goes back to 1996, whereas coverage of the social sciences journal Psychology of Women Quarterly goes back to 1976 . This means that proportionally more of the gathered citations come from social sciences journals - they account for 88 percent of the citing journals, even though they make up "only" 77 percent of the 56 journals sampled (see figure 3).

\section{Discipline Categories of the Cited Sources}

Not all cited sources were assigned a discipline category. Cited sources classified as scholarly journals, academic books, conference papers, and popular books were assigned to one of five broad discipline categories: social sciences, medicine, humanities, science/technology, and law. (These five categories include the four used to categorize the citing journals, plus the science/technology category, which was not used for the citing sources because none of the core scholarly journals in LGBT Life are science or technology journals.) Scholarly journals, academic books, conference papers, and popular books together account for 3,651 of the 4,321 cited sources in the sample, or 84.5 percent. (The other publication types were not categorized by discipline because they are generally multidisciplinary, such as 


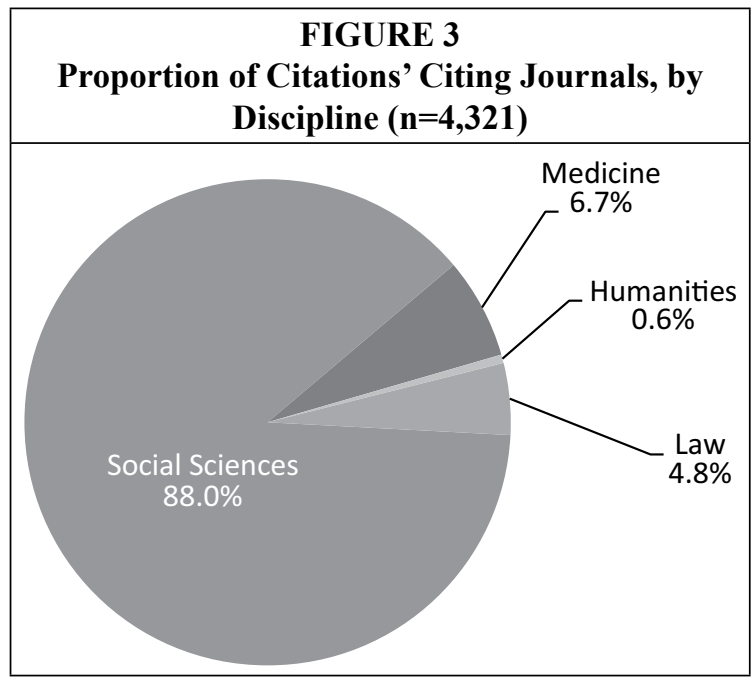

newspapers and popular magazines, or nondisciplinary, such as creative works and many blog posts.) Not surprisingly, the social sciences account for a majority $(63 \%)$ of these cited sources (see figure 4). It is noteworthy, though, that medicine makes up almost a quarter of these cited sources $(24.5 \%)$, considering that medical journals account for only 6.7 percent of citing journals.

When the discipline category is analyzed further by publication type, the results show some striking variations. For instance, 38.2 percent of the citations to scholarly journals are to medical journals, but only 5.4 percent of the citations to academic books are to medical books. This probably is at least a partial reflection of the fact that the field of medicine relies more heavily on journal articles than monographs for scholarly communication. ${ }^{28}$ Likewise, but on the other end of the spectrum, the humanities are known to be more heavily reliant on monographs than journals for scholarly communication. ${ }^{29}$ This is borne out to a striking degree by the findings for the humanities discipline category: 19.2 percent of the citations to academic books are in the humanities category, compared with only 2.6 percent of citations to scholarly journals. These and other variations among the cited sources' publication types are illustrated in figure 5.

\section{Changes in Cited Source Discipline over Time}

When one examines changes in the cited source discipline over time, some variation is noticeable but no particular patterns emerge. For instance, although citations to medical publications represent 24.5 percent of citations overall, this figure ranges quite widely: from 6.5 percent during the 1990-1994 time period to 33.8 percent during the 1995-1999 time period, as shown in figure 6 . But no trend is apparent; the percentage of citations to medical publications appears to vary

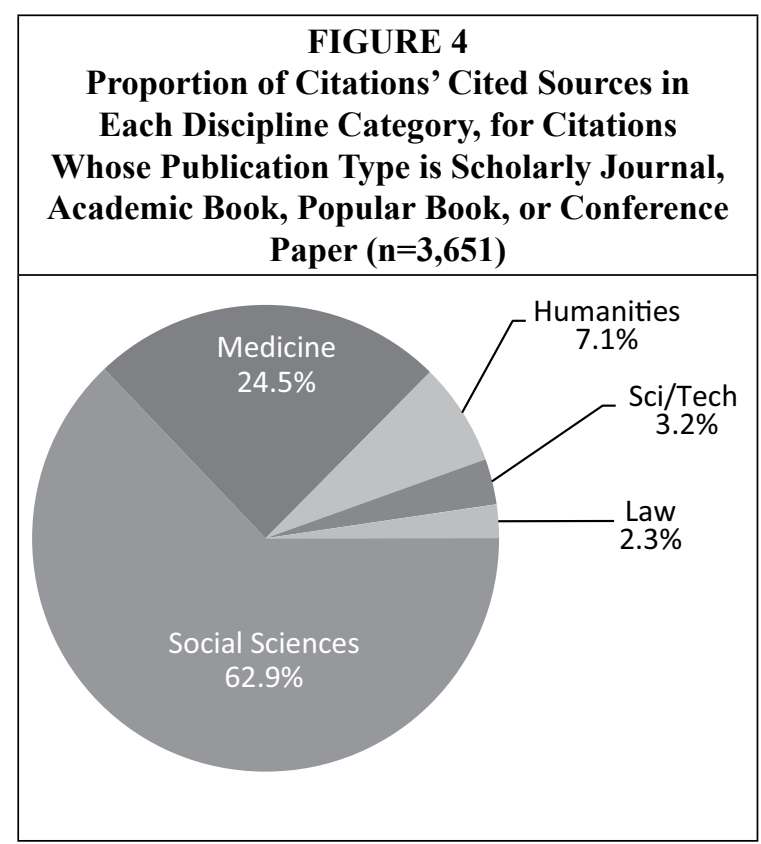




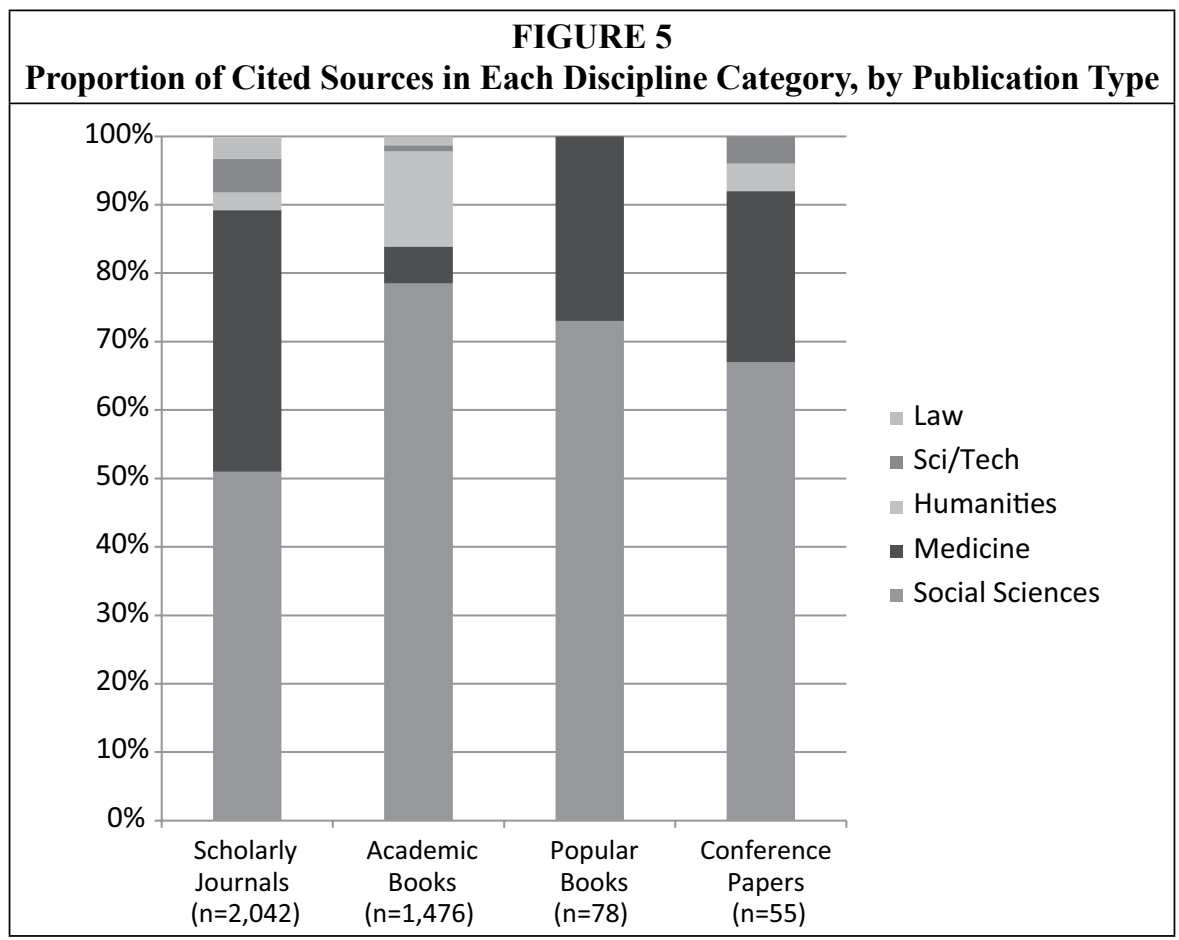

randomly over time. The same is true, although to a less dramatic extent, for all of the five discipline categories, as shown in figure 6.

One obvious prediction is not borne out in these data. Given that the "disease model" of homosexuality was prevalent until 1974, when the American Psychiatric Association "removed homosexuality from the category of a pathological illness, ${ }^{\prime 30}$ it might be natural to suppose that the scholarly literature of LGBT Studies would show a gradual decline in citations to medical literature from the 1970s onward. However, this trend does not appear. Although the citation rate to medical literature declines from the 1970s into the 1980s and early 1990s, it actually increases sharply again in the mid-1990s and remains relatively high through to 2010. It is not clear what explains this phenomenon, although it is possible that, as the disease model declined, biological and explanations of human sexual behaviors became more prominent due to advances in the science of genetics. ${ }^{31}$
Furthermore, the beginning of the AIDS epidemic in the early 1980s and the common perception of it as a "gay disease" ${ }^{\prime 32}$ might lead one to expect a surge of LGBT Studies publications addressing this topic beginning in the mid- to late 1980s, thus increasing the proportion of citations to medical literature; but this pattern also is missing. Although a content analysis of the medical cited works is beyond the scope of this paper, a quick perusal of the medical journals cited most frequently in this study (see table 1) reveals that AIDS and psychiatry are medical themes often referred to in the LGBT Studies scholarly literature. A deeper citation analysis focusing more closely on the kinds of medical literature cited, and perhaps on the citation context or content analysis, would be a welcome addition to the research in this area. Have the cited subfields of medicine changed over time, perhaps from predominantly psychiatry to predominantly genetics? And does the more recent literature tend to cite older "disease model" publica- 


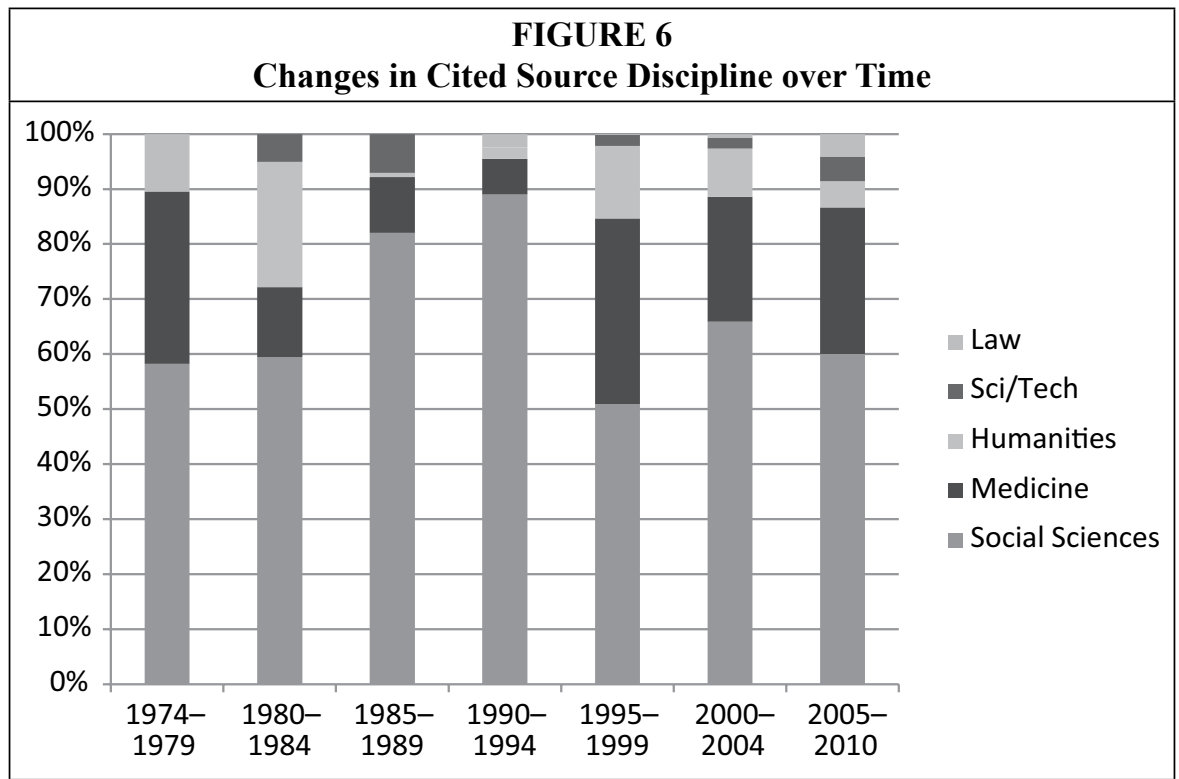

tions mainly to refute them? Research to answer these and related questions would be valuable, but these analyses are beyond the scope of this study.

\section{Out-of-Discipline Citations}

Of the 3,651 citations that were assigned a discipline category, 1,212 of them (33.2\%) are "out-of-discipline" citations: that is, they have a different discipline category than the publication that cited them. The discipline categories used in this study-social sciences, humanities, medicine, law, and science and technology - are very broad, so the threshold for being counted as an out-of discipline citation is quite high. For instance, a psychology journal citing an education reference book does not count as an out-of-discipline citation. Thus, it is striking that the proportion of outof-discipline citations is so large.

Although the overall outof-discipline rate is 33.2 percent, this figure ranges quite widely by citing journal dis- cipline and by year, as shown in figure 7. Only 4.5 percent of citations to social science publications are out of discipline, as opposed to 100 percent of citations to sci-tech publications.

When examined by year, as shown in figure 8 , the out-of-discipline citation rate ranges from a low of 12 percent in the 1990-1994 time period to a high of 42 percent in the 1974-1979 time period. Figure 9 shows the breakdown of out-ofdiscipline citations by both citing journal and cited source. The out-of-discipline

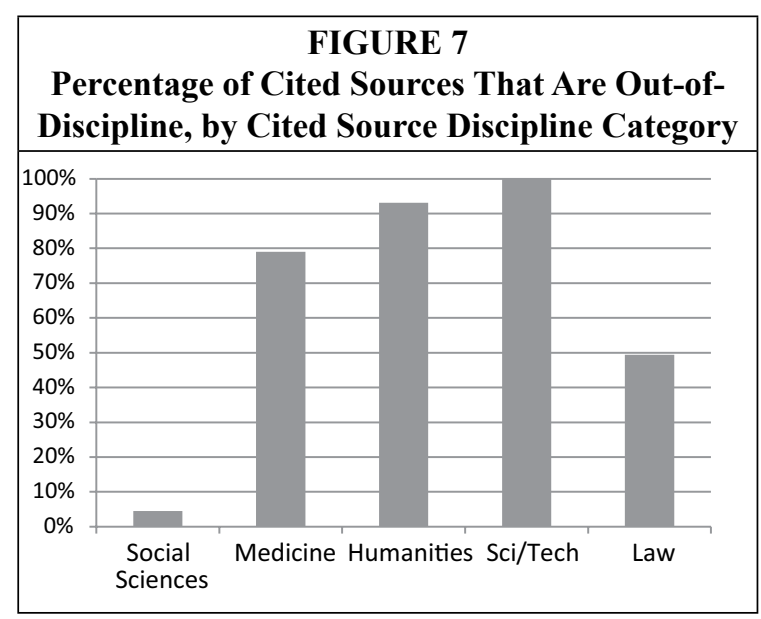




\section{FIGURE 8 \\ Change in the Percentage of Out-of-Discipline Citations over Time}

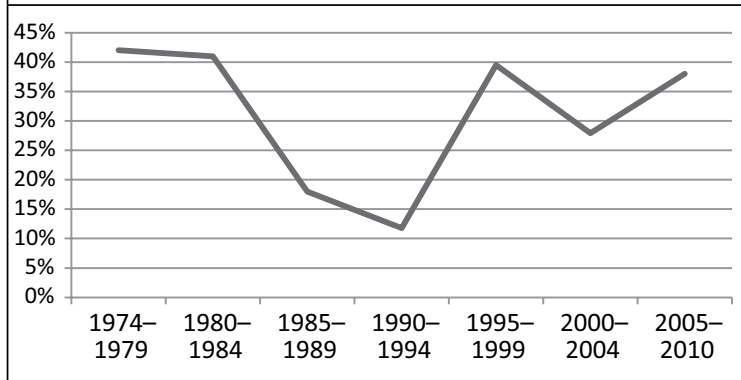

citations in social science journals come overwhelmingly from medicine, at 65.0 percent, followed by the humanities, at 22.6 percent. In the other three citing journal disciplines, the out-of-discipline citations come mainly from the social sciences.

\section{Highly Cited Journals and Books}

Overall, 776 unique scholarly journals titles are cited, for a total of 2,042 scholarly journal citations. Thus, on average, each scholarly journal is cited 2.6 times in the sample. However, the 36 highly cited journals (defined here as those cited 10 times or more) are cited an average of 20.3 times each (see figure 10). In fact, the 36 highly cited journals, which represent less than 5 percent of the cited journal titles, account for fully 35.8 percent of the scholarly journal citations (see figure 11).

Clearly, the highly cited journals (listed in table 1) are very important in the field of LGBT Studies. The "Status in LGBT Life" column of table 1 indicates whether each journal is indexed in LGBT Life and, if so, whether it is indexed fully ("core") or selectively ("priority"). A majority (26 of 36 , or classes.
$72 \%$ ) of the titles on this list are not indexed in LGBT Life. This makes sense, because most of them are not journals specific to LGBT Studies; rather, they are medical journals, psychology journals, and general science journals. However, this is also an indication of how heavily LGBT Studies literature draws on other disciplines; as such, it serves as evidence for subject librarians to use in selecting and maintaining subscriptions to journals outside the "core" LGBT Studies canon, acquiring indexing tools in the general social sciences and medicine, and including medical databases in library instruction for LGBT Studies

On the other hand, the highly cited academic and popular books (defined here as those cited at least three times) show a significantly different pattern. First, the most highly cited book, the American Psychological Association's Diagnostic and Statistical Manual of Mental Disorders, is cited just nine times, as opposed to the most highly cited journal, Archives of Sexual Behavior, which is cited 65 times (see table 2). Second, 1,357 unique books are cited, compared with only 776 unique

\section{FIGURE 9}

\section{Percentage of Out-of-Discipline Citations in Each Cited Source Discipline Category, by Citing Journal Discipline Category}

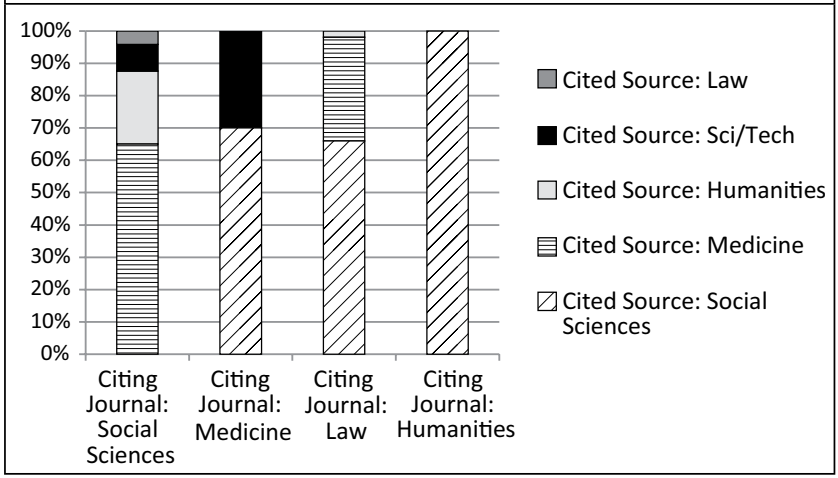




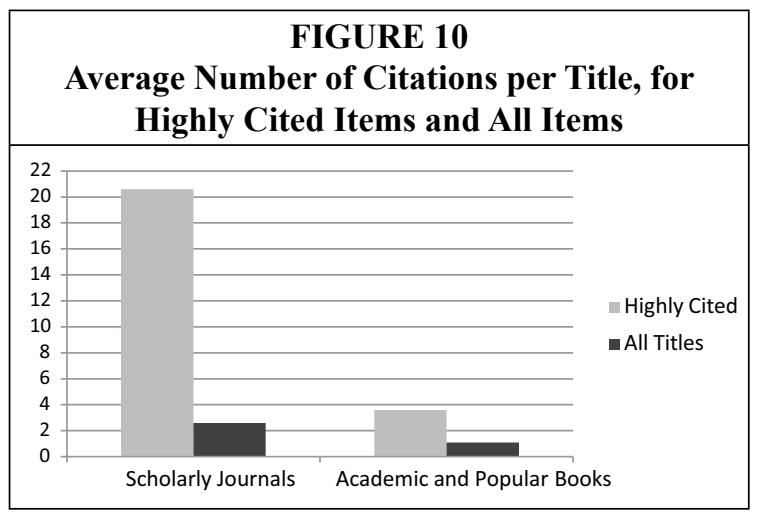

area would therefore add useful evidence for subject librarians faced with making decisions about the purchase of popular books, including self-help books, to support research and teaching.

\section{Cited Source Age}

For the entire sample of 4,321 citations, the average citation age is 13.5 years, and the median is eight years. The range of ages is zero to 351 years

journal titles, even though the overall number of book citations is lower $(1,554)$ than that of journal citations $(2,042)$. As a consequence, even the most highly cited books are cited an average of only 3.6 times each; the comparable figure for highly cited journals is 20.3 times each (see figure 10). Third, the 39 highly cited books, which represent less than 3 percent of all cited books, account for 9.1 percent of the scholarly journal citations. The highly cited journals, on the other hand, represent just under 5 percent of all journals but account for 35.8 percent of all journal citations (see figure 11).

For books, then, it is more difficult to draw conclusions about collection practices. It is interesting, however, that three of the highly cited books are popular books rather than academic books. In fact, all three of them can be considered "self-help" books, a category not often collected by academic libraries. This suggests that subject librarians supporting LGBT Studies programs should not neglect popular and selfhelp literature. Such books might be unlikely to appear on course syllabi, but some of them clearly play a role in the scholarly literature. The use of popular books in scholarly communication has not yet been addressed in the research literature. Additional research in this (for Thomas Hobbes's Leviathan). When the citations are grouped into five-year age intervals, the "citation peak" occurs between five and nine years (see figure 12). Moreover, 56.2 percent of all citations are less than 10 years old, which is congruent with Broadus's findings in his (1971) survey of social science citation analyses. ${ }^{33}$

When the citation set is broken down by publication type, as in figure 12 , the citation age statistics look fairly uniform. Scholarly journals' average citation age is 11.1, with a median of seven. For academic books, the average is 16.1 and the median is 10 . This is not vastly different from Zhang's finding for books: an average age of 14.3 years, and a median age of eight years. ${ }^{34}$ (Zhang did not perform similar calculations for the age of cited journals.) Figure 12 shows clearly that the citation peak occurs between five and nine years for both scholarly journals and academic

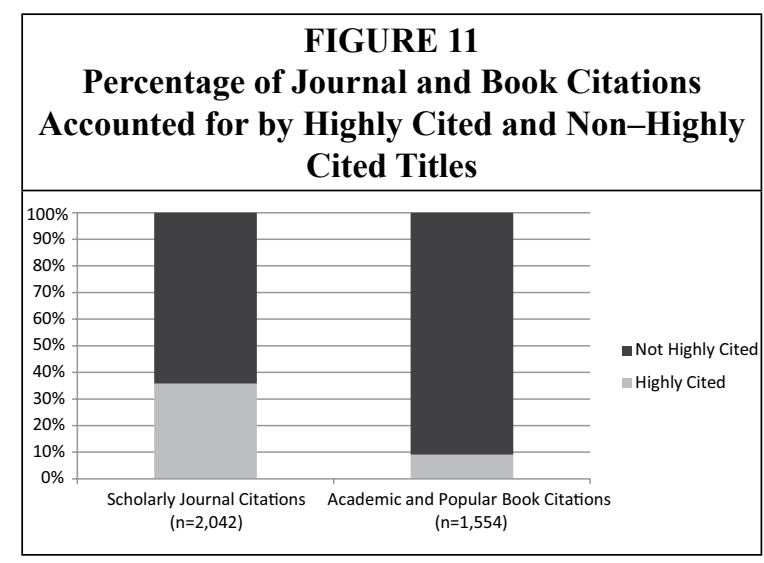




\begin{tabular}{|c|c|c|c|}
\hline \multicolumn{4}{|c|}{$\begin{array}{c}\text { TABLE } 1 \\
\text { List of Highly Cited Journals }\end{array}$} \\
\hline Highly Cited Scholarly Journals & Discipline & $\begin{array}{l}\text { Times } \\
\text { Cited }\end{array}$ & $\begin{array}{l}\text { Status in } \\
\text { LGBT Life }\end{array}$ \\
\hline Archives of Sexual Behavior & Medicine & 65 & Core \\
\hline Journal of Homosexuality & Social Sciences & 44 & Core \\
\hline Journal of Personality and Social Psychology & Social Sciences & 36 & Not Indexed \\
\hline Journal of Sex Research & Social Sciences & 33 & Core \\
\hline Journal of Sex and Marital Therapy & Social Sciences & 32 & Not Indexed \\
\hline Hormones and Behavior & Medicine & 30 & Not Indexed \\
\hline Journal of the American Medical Association & Medicine & 29 & Not Indexed \\
\hline Journal of Consulting and Clinical Psychology & Social Sciences & 28 & Not Indexed \\
\hline Sex Roles & Social Sciences & 27 & Core \\
\hline Health Affairs & Social Sciences & 24 & Not Indexed \\
\hline New England Journal of Medicine & Medicine & 24 & Not Indexed \\
\hline AIDS & Medicine & 21 & Not Indexed \\
\hline AIDS Care & Medicine & 20 & Priority \\
\hline Journal of Marriage and Family & Social Sciences & 19 & Priority \\
\hline Physiology and Behavior & Sci/Tech & 19 & Not Indexed \\
\hline Science & Sci/Tech & 19 & Not Indexed \\
\hline American Journal of Psychiatry & Medicine & 17 & Not Indexed \\
\hline Social Work & Social Sciences & 17 & Not Indexed \\
\hline Psychology of Women Quarterly & Social Sciences & 16 & Core \\
\hline American Journal of Public Health & Social Sciences & 15 & Priority \\
\hline Endocrinology & Medicine & 15 & Not Indexed \\
\hline Journal of Counseling Psychology & Social Sciences & 15 & Not Indexed \\
\hline Signs: Journal of Women in Culture and Society & Social Sciences & 15 & Core \\
\hline Psychological Bulletin & Social Sciences & 14 & Not Indexed \\
\hline $\begin{array}{l}\text { Journal of the American Academy of Child and } \\
\text { Adolescent Psychiatry }\end{array}$ & Medicine & 14 & Not Indexed \\
\hline British Journal of Psychiatry & Medicine & 13 & Not Indexed \\
\hline American Psychologist & Social Sciences & 12 & Not Indexed \\
\hline British Medical Journal & Medicine & 12 & Not Indexed \\
\hline Counseling Psychologist & Social Sciences & 12 & Not Indexed \\
\hline Journal of Interpersonal Violence & Social Sciences & 12 & Not Indexed \\
\hline Journal of Urology & Medicine & 12 & Not Indexed \\
\hline Social Science and Medicine & Medicine & 11 & Not Indexed \\
\hline $\begin{array}{l}\text { Journal of Behavior Therapy and Experimental } \\
\text { Psychiatry }\end{array}$ & Medicine & 10 & Not Indexed \\
\hline Journal of Infectious Disease & Medicine & 10 & Not Indexed \\
\hline Sexually Transmitted Diseases & Medicine & 10 & Priority \\
\hline Social Work in Health Care & Social Sciences & 10 & Not Indexed \\
\hline
\end{tabular}




\begin{tabular}{|c|c|c|c|c|}
\hline \multicolumn{5}{|c|}{$\begin{array}{c}\text { TABLE } 2 \\
\text { List of Highly Cited Books }\end{array}$} \\
\hline $\begin{array}{l}\text { Highly Cited Academic and } \\
\text { Popular Books }\end{array}$ & $\begin{array}{c}\text { Year } \\
\text { Published }\end{array}$ & Discipline & $\begin{array}{l}\text { Academic } \\
\text { or Popular }\end{array}$ & $\begin{array}{l}\text { Times } \\
\text { Cited }\end{array}$ \\
\hline $\begin{array}{l}\text { Diagnostic \& Statistical Manual of } \\
\text { Mental Disorders (various editions) }\end{array}$ & various & Social Sciences & Academic & 9 \\
\hline History of Sexuality & 1978 & Social Sciences & Academic & 7 \\
\hline Out and About on Campus & 2000 & Social Sciences & Popular & 6 \\
\hline $\begin{array}{l}\text { Labour and Love: Women's } \\
\text { Experience of Home and Family }\end{array}$ & 1986 & Social Sciences & Academic & 5 \\
\hline $\begin{array}{l}\text { Physical Violence in American } \\
\text { Families }\end{array}$ & 1990 & Social Sciences & Academic & 5 \\
\hline $\begin{array}{l}\text { Sexual Behavior in the Human } \\
\text { Female }\end{array}$ & 1953 & Social Sciences & Academic & 5 \\
\hline $\begin{array}{l}\text { Conceiving the New World Order: } \\
\text { The Global Politics of Reproduction }\end{array}$ & 1995 & Social Sciences & Academic & 4 \\
\hline $\begin{array}{l}\text { Forms of Desire: Sexual } \\
\text { Orientation and the Social } \\
\text { Constructionist Controversy }\end{array}$ & 1990 & Social Sciences & Academic & 4 \\
\hline $\begin{array}{l}\text { Neurophysiological Basis of } \\
\text { Normal and Abnormal Motor } \\
\text { Activities }\end{array}$ & 1967 & Medicine & Academic & 4 \\
\hline $\begin{array}{l}\text { Scattered Hegemonies: } \\
\text { Postmodernity \& Transnational } \\
\text { Feminist Practices }\end{array}$ & 1994 & Humanities & Academic & 4 \\
\hline Sexual Behavior in the Human Male & 1948 & Social Sciences & Academic & 4 \\
\hline $\begin{array}{l}\text { Third World Women and the Politics } \\
\text { of Feminism }\end{array}$ & 1991 & Social Sciences & Academic & 4 \\
\hline $\begin{array}{l}\text { Abortion Wars: A Half Century of } \\
\text { Struggle }\end{array}$ & 1998 & Social Sciences & Academic & 3 \\
\hline $\begin{array}{l}\text { Aging in Canada: Social } \\
\text { Perspectives }\end{array}$ & 1987 & Social Sciences & Academic & 3 \\
\hline $\begin{array}{l}\text { American Couples: Money, Work, } \\
\text { Sex }\end{array}$ & 1983 & Social Sciences & Popular & 3 \\
\hline Becoming Orgasmic & 1988 & Medicine & Popular & 3 \\
\hline $\begin{array}{l}\text { Becoming Visible: Women in } \\
\text { European History }\end{array}$ & 1987 & Social Sciences & Academic & 3 \\
\hline $\begin{array}{l}\text { Civil Liberties vs. National Security } \\
\text { in a Post-9/11 World }\end{array}$ & 2004 & Law & Academic & 3 \\
\hline Close Relationships & 1983 & Social Sciences & Academic & 3 \\
\hline $\begin{array}{l}\text { Current Concepts in Transgender } \\
\text { Identity }\end{array}$ & 1998 & Social Sciences & Academic & 3 \\
\hline $\begin{array}{l}\text { De/Colonizing the Subject: The } \\
\text { Politics of Gender in Women's } \\
\text { Autobiography }\end{array}$ & 1992 & Humanities & Academic & 3 \\
\hline
\end{tabular}




\begin{tabular}{|c|c|c|c|c|}
\hline \multicolumn{5}{|c|}{$\begin{array}{c}\text { TABLE } 2 \\
\text { List of Highly Cited Books }\end{array}$} \\
\hline $\begin{array}{l}\text { Highly Cited Academic and } \\
\text { Popular Books }\end{array}$ & $\begin{array}{c}\text { Year } \\
\text { Published }\end{array}$ & Discipline & $\begin{array}{l}\text { Academic } \\
\text { or Popular }\end{array}$ & $\begin{array}{l}\text { Times } \\
\text { Cited }\end{array}$ \\
\hline Discovery of Grounded Theory & 1967 & Social Sciences & Academic & 3 \\
\hline $\begin{array}{l}\text { Feminist Contentions: } A \\
\text { Philosophical Exchange }\end{array}$ & 1995 & Humanities & Academic & 3 \\
\hline $\begin{array}{l}\text { Feminist Theorists: Three Centuries } \\
\text { of Key Women Thinkers }\end{array}$ & 1983 & Social Sciences & Academic & 3 \\
\hline $\begin{array}{l}\text { Gender Trouble: Feminism and the } \\
\text { Subversion of Identity }\end{array}$ & 1990 & Social Sciences & Academic & 3 \\
\hline $\begin{array}{l}\text { Handbook of Counseling with } \\
\text { Lesbian, Gay, and Bisexual Clients }\end{array}$ & 2000 & Social Sciences & Academic & 3 \\
\hline $\begin{array}{l}\text { Homeland Security and Terrorism: } \\
\text { Readings and Interpretations }\end{array}$ & 2006 & Social Sciences & Academic & 3 \\
\hline $\begin{array}{l}\text { Homosexuality, Which } \\
\text { Homosexuality }\end{array}$ & 1989 & Social Sciences & Academic & 3 \\
\hline Married Women's Work & 1915 & Social Sciences & Academic & 3 \\
\hline Multiculturalism: A Critical Reader & 1994 & Social Sciences & Academic & 3 \\
\hline Rhetoric of Law & 1994 & Law & Academic & 3 \\
\hline Selected Melanie Klein & 1991 & Social Sciences & Academic & 3 \\
\hline $\begin{array}{l}\text { Sexual Conduct: The Social Sources } \\
\text { of Human Sexuality }\end{array}$ & 1973 & Social Sciences & Academic & 3 \\
\hline Shock and Awe: War on Words & 2004 & Humanities & Academic & 3 \\
\hline Social Organization of Sexuality & 1994 & Social Sciences & Academic & 3 \\
\hline $\begin{array}{l}\text { Theory and Practice of } \\
\text { Homosexuality }\end{array}$ & 1981 & Social Sciences & Academic & 3 \\
\hline $\begin{array}{l}\text { Unequal Opportunities: Women's } \\
\text { Employment in England, 1800- } \\
1918\end{array}$ & 1986 & Social Sciences & Academic & 3 \\
\hline Vindication of the Rights of Whores & 1989 & Law & Academic & 3 \\
\hline $\begin{array}{l}\text { Women, Girls, and Psychotherapy: } \\
\text { Reframing Resistance }\end{array}$ & 1991 & Social Sciences & Academic & 3 \\
\hline
\end{tabular}

books, but the peak is more pronounced for academic books. Again, these results are congruent with other researchers' findings. Burtis and Taylor's 2010 study is just one of many finding that "older books continue to be cited more frequently than older materials in other categories." 35

When the citation set is analyzed by discipline category, however, a few interesting differences emerge. First, medical publications' citation peak occurs during the first five-year age interval rather than the second (see figure 13). Apparently, medical information is most valuable when it is freshest. Second, although "older citations" (defined here as those at least 50 years old) make up just 3.6 percent of citations overall, it is clear that some categories of publication remain relatively important even in their old age. As figure 14 shows, academic books tend to be used much more heavily than 


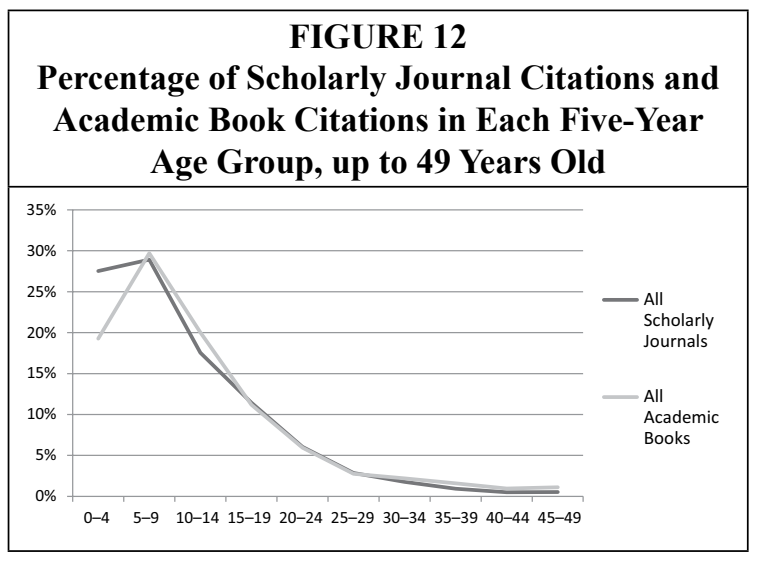

the relevant literature-but which ones?

Examining the out-of-database citations by discipline category makes it clear that the needed tools are those that provide access to the social sciences and medical literature: cited journals in the social sciences and medicine account for 48.9 percent and 38.4 percent of out-of-database citations respectively, or a total of 87.3 percent. In acquiring index-

scholarly journals after 50 years. This is particularly striking for medical books: almost 14 percent of citations to medical books are more than 50 years old.

\section{In-Database Status}

Of the 2,042 citations to scholarly journals, just $350(17.1 \%)$ are "in-database" citations, meaning that the cited journal is indexed in LGBT Life. For the 732 citations to highly cited journals, the proportion more than doubles: $263(35.9 \%)$ are citations to LBGT Life journals. In both cases, though, the majority of citations are "out of database," meaning that LGBT Studies scholars and students require access to other databases and indexing tools to capture a more complete range of ing tools and in providing library instruction, subject librarians for LGBT Studies are likely to focus on LGBT Life and the important indexes in allied social science disciplines, such as psychology, sociology, and social work. However, they would do well also to keep in mind how very central the medical literature is to LGBT Studies scholarship. Clearly, to support students and faculty in this discipline, it is crucial to provide access to medical databases, include medical resources in LGBT Studies research guides, and teach medical searching during library instruction.

\section{Conclusions}

This citation analysis reveals several interesting patterns in literature use

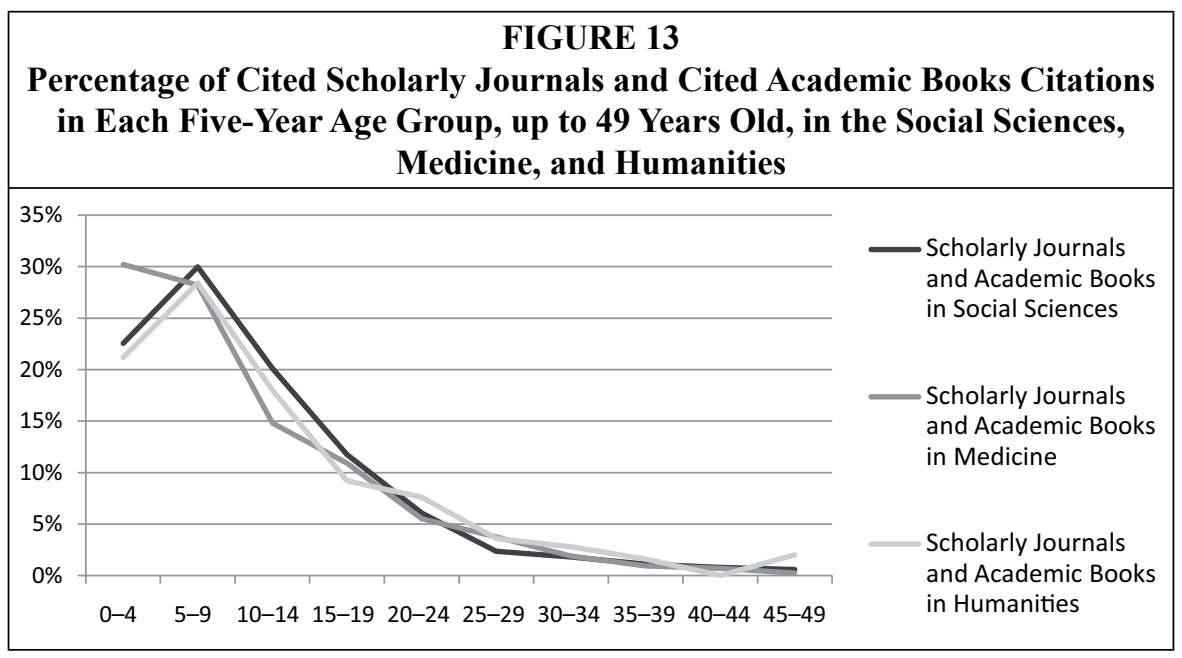




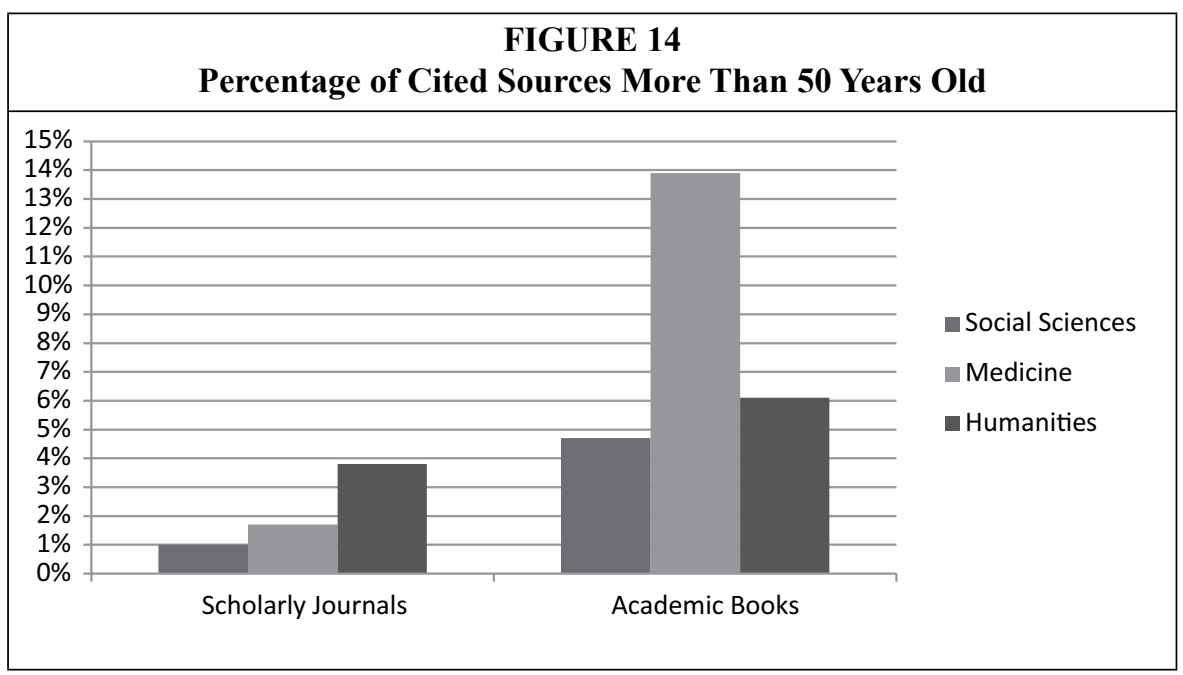

among scholars in LGBT Studies. One notable finding is the extent to which the LGBT Studies literature draws upon the medical literature: A few medical journals are included among the core scholarly journals in LGBT Life, but despite providing a mere 6.7 percent of all citing sources, medical materials account for fully 24.5 percent of all cited sources. In other words, the medical literature is cited a great deal more than its contribution to the LGBT Studies literature would suggest. This is not the result of heavy "self-citation" within the medical journals; rather, it is due to the fact that LGBT Life's many social science journals have highly cross-disciplinary citation patterns, citing especially heavily from medical sources. AIDS and psychiatry are two areas of medicine that appear to be heavily cited, but additional research is needed to reveal more precisely how and why LGBT Studies scholars use the medical literature.

Although LGBT Studies itself emerged from the gay rights activist movement of the 1960s and 1970s, the field's scholarly literature appears to be firmly rooted in the mainstream academic literature rather than in popular publications or community and activist periodicals. Scholarly journals and academic books make up 81.5 percent of the cited sources in this study, a finding that is similar to the results found by most other researchers conducting citation analyses in other social sciences disciplines.

LGBT Studies might be a new field, but, with regard to the age of cited sources, its literature appears to be quite similar to that of most other social sciences: the majority of the cited sources are less than 10 years old, the cited half-life (median age) is eight years, and the age of citations tapers off gradually past the 10year mark. However, some sources more than 50 years old remain important: books more than journals, and medical books more than books in other disciplines. Clearly, the field's newness does not affect the depth of its roots in the scholarly literature; like other interdisciplinary social sciences, it draws on an established body of scholarship both within and outside the social sciences. This suggests that subject librarians responsible for LGBT Studies programs should take care when deselecting older items from their collections. Although LGBT Studies itself did not exist as an academic program or field of scholarship 50 years ago, certain older books and journals from other fields should be recognized as forming a foundational core for LGBT Studies. Subject librarians would be well advised to identify these core items in their collections and work 
with subject librarians in other fields to ensure that access is maintained to support LGBT Studies patrons.

The use of popular books and periodicals is an aspect of this study's results that would be particularly fruitful for further research. Although this study found that only 6 percent of all cited sources were popular books and periodicals, it is difficult to determine whether this is typical of social science disciplines, both because so few other studies have reported on the use of popular materials and because those that do so report such varying results. Three of the books on the "highly cited books" list are popular self-help books, a genre not typically collected by academic libraries. More information about the use of popular books in LGBT Studies scholarship would give subject librarians the evidence they need to make better informed collection decisions.

EBSCO's LGBT Life does an admirable job of indexing the most important scholarly journals and other materials in LGBT Studies. But this citation analysis demonstrates that subject librarians cannot rely on it alone to support LGBT Studies programs. For collection development, electronic resource acquisition, and library instruction, subject librarians should bear in mind the field's broad interdisciplinarity and help students and scholars access other sources, especially in medicine and the allied social science disciplines.

\section{Notes}

1. John Younger, "University Queer Programs," 2011, available online at www.people. ku.edu/ jyounger/lgbtqprogs.html [accessed 21 October 2011]; City College of San Francisco, "The First Queer Studies Department in the U.S.," 2007, available online at www.ccsf.edu/Departments/ Gay_Lesbian_Bisexual_Studies/department_history.html [accessed 21 October 2011].

2. Younger, 2011; Joel Steinberg, "Harvard to Endow Professorship in Gay Studies," New York Times (June 4, 2009): A19.

3. Younger, "University Queer Programs."

4. Ibid.

5. Liesel Tyson, "LGBT Studies" (Boston College subject guide), 2011, available online at http://libguides.bc.edu/content.php?pid=12796\&sid=85664 [accessed 21 October 2011]; Bonnie Ryan, "LGBT Studies" (Syracuse University research guide), 2008, available online at http:// researchguides.library.syr.edu/lgbt [accessed 21 October 2011]. 32.

6. Cheryl LaGuardia, "Queer Content Comes Out," Library Journal 130, no. 7 (Apr. 15, 2005):

7. Molly Strothmann, "Use of Non-Social-Work Journals in Social Work Research: Results of a Citation Analysis," Behavioral and Social Sciences Librarian 29 (2010): 244-66.

8. Thomas Weissinger, "Black Studies Scholarly Communications: A Citation Analysis of Periodical Literature," Collection Management 27, no. 3/4 (2002): 45-56; Thomas Weissinger, "The Core Journal Concept in Black Studies," Journal of Academic Librarianship 36, no. 2 (Mar. 2010): $119-24$.

9. Weissinger, "Black Studies Scholarly Communications," 53.

10. Li Zhang, "Citation Analysis for Collection Development: A Study of International Relations Journal Literature," Library Collections, Acquisitions, and Technical Services 31 (2007): 195-207.

11. Strothmann, "Use of Non-Social-Work Journals," 252.

12. Joy Thomas, "Never Enough: Graduate Student Use of Journals-Citation Analysis of Social Work Theses," Behavioral and Social Sciences Librarian 19, no. 1 (2000): 1-16; Weissinger, "The Core Journal Concept."

13. Weissinger, "The Core Journal Concept."

14. Robert N. Broadus, "The Literature of the Social Sciences: A Survey of Citation Studies," International Social Sciences Journal 23 (1971): 236-43.

15. Penelope Earle and Brian Vickery, "Social Science Literature Use in the UK as Indicated by Citations," Journal of Documentation 25, no. 2 (1969): 123-41.

16. Jonathan M. Levitt, Mike Thelwall, and Charles Oppenheim, "Variations between Subjects in the Extent to Which the Social Sciences Have Become More Interdisciplinary," Journal of the American Society for Information Science and Technology 62, no. 6 (2011): 1118-29. 
17. Amber T. Burtis and Mary K. Taylor, "Mapping the Literature of Health Education: 2006-2008," Journal of the Medical Library Association 98, no. 4 (Oct. 2010): 293-99.

18. Katherine W. McCain, "Cross-Disciplinary Citation Patterns in the History of Technology," Proceedings of the ASIS Annual Meeting 23 (1986): 194-98.

19. Zhang, "Citation Analysis," 199.

20. Broadus, "The Literature of the Social Sciences," 240-41.

21. Nazan Özenç Uçak and Umut Al, "The Differences among Disciplines in Scholarly Communication," Libri 59 (2009): 166-79.

22. Burtis and Taylor, "Mapping the Literature," 296; Broadus, "The Literature of the Social Sciences," 241-42; Zhang, "Citation Analysis," 196, 203-05; Earle and Vickery, "Social Sciences Literature Use," 131-32.

23. Earle and Vickery, "Social Science Literature Use," 132.

24. Zhang, "Citation Analysis"; Earle and Vickery, "Social Science Literature Use."

25. Burtis and Taylor, "Mapping the Literature," 295; Zhang, "Citation Analysis."

26. Weissinger, "Black Studies Scholarly Communications," 50.

27. Zhang, "Citation Analysis," 199.

28. Burtis and Taylor, "Mapping the Literature," 295.

29. McCain, "Cross-Disciplinary Citation Patterns"; Jennifer E. Knievel and Charlene Kellsey, "Citation Analysis for Collection Development: A Comparative Study of Eight Humanities Fields," Library Quarterly 75, no. 2 (2005): 142-68.

30. Vern L. Bullough, "Sex and the Medical Model," Journal of Sex Research 11, no. 4 (Nov. 1975): 291-303.

31. See, for example, Guy A. Boysen and David L. Vogel, "Biased Assimilation and Attitude Polarization in Response to Learning about Biological Explanations of Homosexuality," Sex Roles 57, vol. 9/10 (2007): 755-62; and Aaron S. Greenberg and J. Michael Bailey, "Do Biological Explanations of Homosexuality Have Moral, Legal, or Policy Implications?" Journal of Sex Research 30, no. 3 (Aug. 1993): 24-51.

32. See, for example, Jeffrey A. Kelly, Janet S. St. Lawrence, Steve Smith, Jr., Harold V. Hood, and Donna J. Cook, "Stigmatization of AIDS Patients by Physicians," American Journal of Public Health 77, no. 7 (1987): 789-91; and Vickie M. Mays and Susan D. Cochran, "Acquired Immunodeficiency Syndrome and Black Americans: Special Psychosocial Issues," Public Health Reports 102, no. 2 (1987): 224-31.

33. Broadus, "The Literature of the Social Sciences," 241.

34. Zhang, "Citation Analysis."

35. Burtis and Taylor, "Mapping the Literature," 296. 